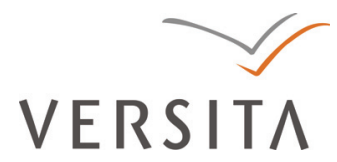

Folia Oeconomica Stetinensia

DOI: $10.2478 / \mathrm{v} 10031-011-0005-2$

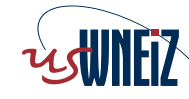
Wydzial Nauk Ekonomicznych i Zarządzania
Uniwersytetu Szzzecińskiego

\title{
OFFSHORING IN BUSINESS SERVICES SECTOR OVER THE BUSINESS CYCLE: A CASE OF GROWTH OF THE INTERNATIONAL COOPERATION
}

Eliza Chilimoniuk-Przeździecka, Ph.D.

Institute of International Economics

Warsaw School of Economics

echili@sgh.waw.pl

Received 20 June 2011, Accepted 30 July 2011

\begin{abstract}
In this paper I analyze the role of business service offshoring in international cooperation over the recession. In business services - as described in Schumpeterian literature - external restructuring including resource and production relocation is more intensive during recession periods while intensive internal restructuring accompanies expansion periods. As external restructuring encompass business processes fragmentation and offshoring of services, I also argue - taking into account historical evidence - that current economic crisis would result in growing service offshoring in business service sector. I expect that many financial institutions would relocate part of their business processes abroad, where operating costs are lower, as they find that external restructuring via offshoring is the way to survive. This, in turn, will be the most possible result in growth of service offshoring projects located in CEE and Asia, as these two locations were the most attractive ones in recent years for service offshoring. The process is reflected by growth of FDI outflows from developed economies to CEE and Asia as well as growth of business and IT services trade between the mentioned economies. However, I also expect that in short run (one year perspective) we will experience tremendous decrease of FDI flows including investment in service offshoring, nevertheless the share of FDI flows related to service offshoring in total FDI flows will increase.
\end{abstract}

Keywords: FDI, offshoring, economic crisis.

JEL classification: D21, G 21, L14, O16. 


\section{Introduction}

Business cycle definitively affects business services what is clearly seen in FDI statistics and financial results of all companies operating in this sector. Internal and external restructuring is recognized as a chance for business improvement and has been going through dramatic changes since the middle of 2008. As it is proved in Schumpeterian literature, that restructuring is more intensive in crisis than internal restructuring, which accompanies expansion periods ${ }^{1}$. Ongoing financial crisis, the worse in the last 60 years, raises numbers of projects external restructuring including resource and production relocation.

As external restructuring encompass business process fragmentation and offshoring of services, I also state - taking into account historical evidence - that current economic crisis would result in growing service offshoring in business service sector.

I expect that many business service providers would relocate part of their business processes abroad, where operating costs are lower, as they find that external restructuring via offshoring is the way to survive. Data reported by UNCTAD in World Investment Prospects Survey 2009-2011 augurs this trend in FDI flows.

This, in turn, will be the most possible result in growth of service offshoring projects located in CEE (Poland, Hungary and Czech Republic), as locations were the most attractive in the recent years for service offshoring. The process is reflected by growth of FDI outflows from developed economies and FDI inflows in CEE as well as growth of business services trade between the mentioned regions.

However, it is expected that in short run (one year perspective) we will experience slight decrease of FDI flows including investment in service offshoring, nevertheless the share of FDI flows related to service offshoring in total FDI flows will increase. In medium term perspective we expect both increase of total FDI including these related to service offshoring.

How crisis affected this sector? When many companies sent out alarming information about declining turnovers and necessary restructuring since the crisis started to hurt them, the market of business services in Poland has grown by about 50\% in 2009-2010². In the region of CEE Poland has grown as the leader of this sector leaving Czech Republic or Hungary far away. There are still large interests revealed by the foreign investors, which are going to open their service centers in Poland. 


\section{Offshoring of business services}

Recent achievements of globalization have already outlined the obvious path for further business developments. High-speed fiber optic networks, development in telecommunication and information technologies resulted in enormous integration of financial markets and intensification of cross-border flow of services. Low-cost labor, labor cost reduction, but well skilled, developed technology services, and back office work specialization seem to be additional factors affecting in improvement of country's comparative advantage.

Production in China, call-centers in Philippines, software development centers in Russia, financial services in Poland or back-office in India are renowned examples of successful offshoring specialization. Unfortunately, current recession effects are expected to affect in trade in services as well as FDI done by financial institutions, and multinational companies (MNCs).

Business service offshoring faces numbers of distortions due to the economic crisis, that shocked financial markets as in developed well as developing countries. Financial services institutions, main victims of the crisis, are the main clients of business services providers from India, Russia or Poland. More than $40 \%$ of Indian IT and business service export is delivered to banks and other financial companies worldwide. Accordingly, European and American financial institutions have already reduced their outsourcing activities consequently to the financial crisis. They have cut their IT contracts by nearly 30 percent in 2008 compared to the previous year. According to recent UNCTAD report ${ }^{3}$, foreign direct investment in China has dropped down in 2009 comparing to the previous year by $13 \%$. As the response to the global economics crisis investors froze businesses. Consequently investment fell from 108.3 bln USD in 2008 to 95 bln USD in 2009.

With above exception, another official statistics published by now do not reveal many crisis effects in particular industry. Nevertheless, the UNCTAD survey findings, and some historical data 1997-2009 presenting the effects of crisis in 2001-2003 in trade and FDI in financial services prove the theories of internal and external restructuring in crisis.

Outsourcing, especially business process outsourcing in financial institution enables risk transfer, management and compliance to third parties who may not be regulated, and who may operate offshore. Service provider operates with specialization and cost-reduction due to economies of scale, so that the most important goal of business recovery plans in crisis is cost reduction.

Crisis symptoms are usually seen on FDI flows. The time of crisis at the beginning of XXI century is revealed in the value of FDI, which has been substantially declining in 2001-2003. 
FDI inflow reached minimum value in Poland at the end of 2002, and in OECD countries at the end of 2003. But later on, FDI surprisingly increased especially in transforming economies, as Poland and other CEE countries. FDI flow has been recently strongly affected by recession and market fluctuations. FDI has declined by half in the middle of 2009 comparing to 2008. That dramatically fall is clearly seen in FDI outflow of developed countries and FDI inflow to Poland as well (see Figure 1).

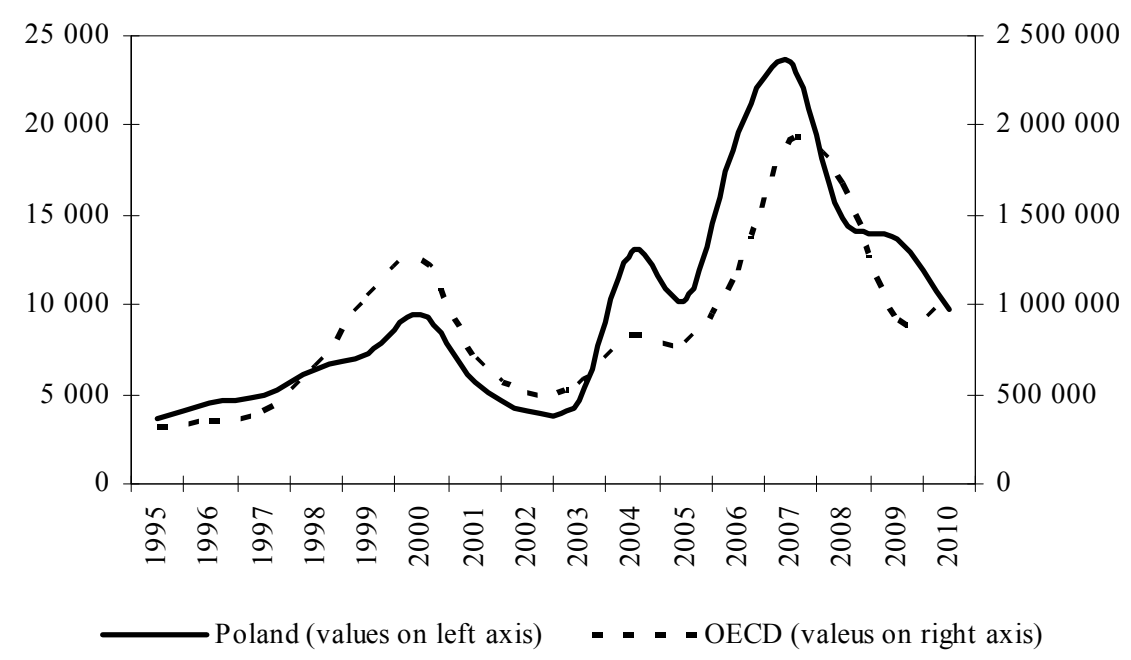

Fig. 1. FDI inward in Poland and FDI outward by OECD countries (million US dollars)

Source: OECD Stat, http://stats.oecd.org/OECDStat_Metadata/ShowMetadata.ashx?Dataset=FDI_BOP_IIP\&Show OnWeb=true\&Lang=en; data downloaded on 19.06.2011.

Substantial FDI inflow was the effect of the improvement in economic environment in CEE, relatively lower (than in Western countries) cost of labor, development in infrastructure and so on. The most dynamic growth of the FDI inflows in CEE countries was noticed before the crisis: 2003-2006. Surprising annual growth rate of FDI in business services in 2003-2006 was noticed in Bulgaria 77\%, followed by Romania 68\%, Ukraine 65\% and Estonia 44\%. FDI inward in business services in 2003-2006 has been increasing in CEE countries annually by $43,19 \%$ in average.

Poland as the biggest FDI receiver is competitive enough to catch up many of its regional competitors. With 5.66 million sq. meters of modern office space Poland is the largest office market in CEE region. Warsaw supplies a 31\% share in total 11 sq. meters office stock offered by Warsaw, Prague, Budapest, and Bucharest ${ }^{4}$. 


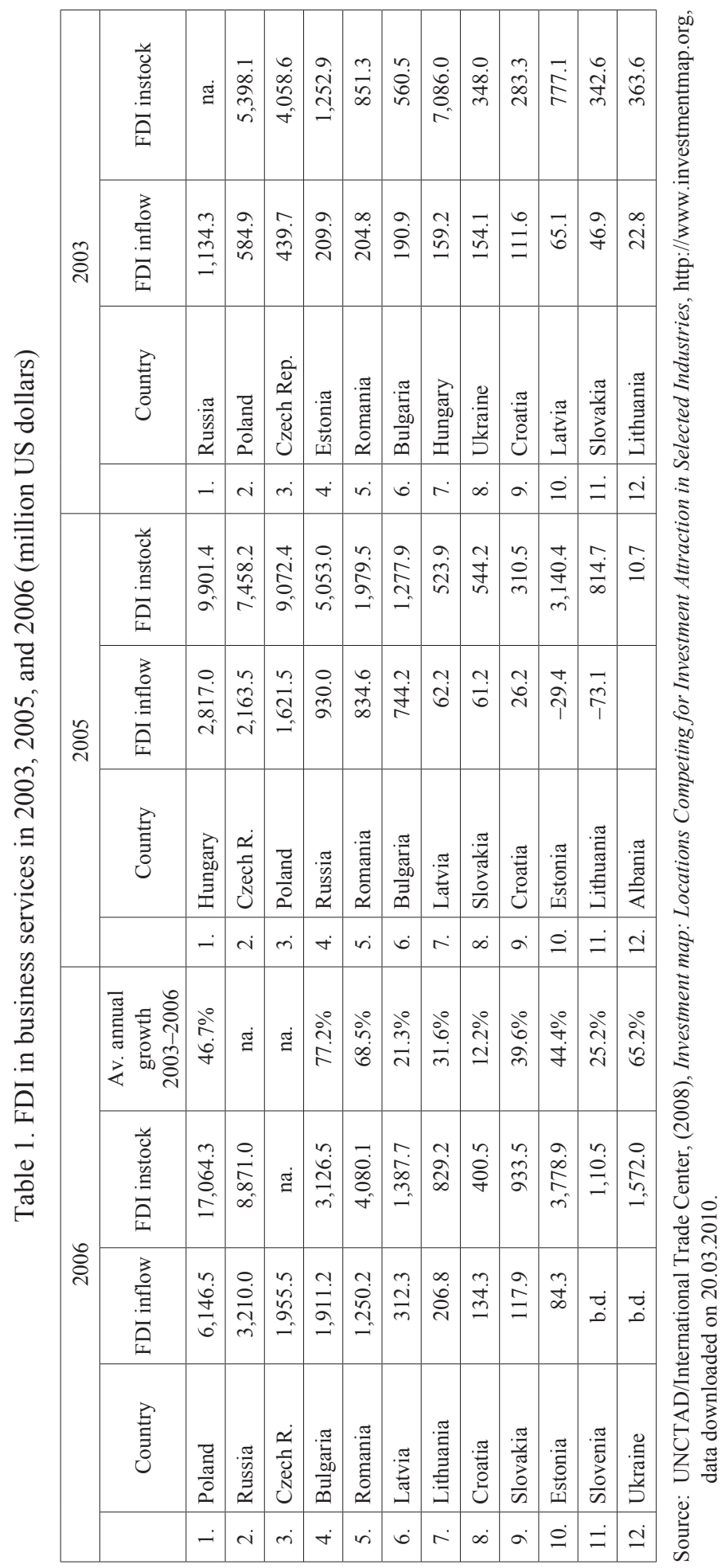


Significant change in the structure of FDI cannot be missed. First of all, there is a growing value of FDI outward in services in developed countries (in analyze OECD). Secondly, services are more and more important in total value of FDI flows. But what needs to be stressed that a growth in the value of FDI flow of financial intermediation and Other business activities refers to growing interests of this investors in starting business abroad ${ }^{5}$.

Business service offshoring is one of the key features of globalization as well as the incentive of reduction in cost of operation. As FDI values show, business services are getting more and more important subject of investment. It is seen in statistics concerning Other business services ${ }^{6}$.

Picture below presents the value of FDI outward (investment done) in following sectors: financial intermediation and other business services from OECD countries.

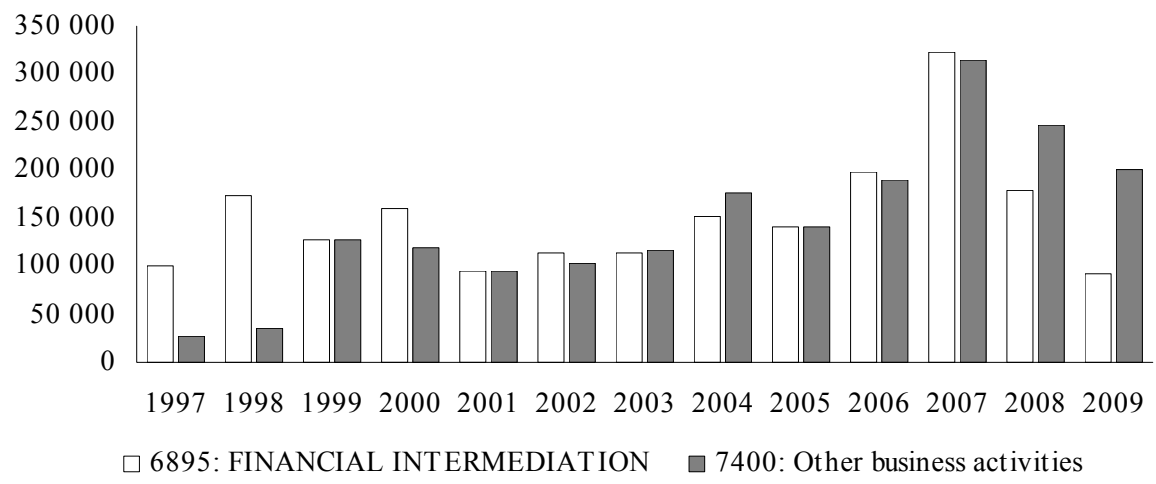

Note: aggregated data for: Austria, Belgium, Denmark, Finland, France, Germany, Italy, Japan, Netherlands, Spain, Sweden, United Kingdom, United States.

Fig. 2. FDI outward in selected OECD countries (million US dollars)

Source: OECD Stat, http://stats.oecd.org/Index.aspx; data downloaded on 15.05.2011.

The second part of 90s was the time, when foreign investors in Other business services just entered onto the market. A slight decrease in investment is noted in 2001-2002, but after that time, other business FDI outward from OECD has been increasing. The year of 2004 started with a substantial increase of FDI outward done by financial institutions and also by firms that started their business on foreign markets and prepared to serve in business services such as: legal, accounting, management consulting. Growing value of Other business activities investment affects further offshoring activities in countries, where investments are placed. Since 2008 Other business services revealed greater importance in value than Financial intermediation. It is 
another aspect worth to stress, that during the crisis, the value of business services offshoring transaction is expected to rise.

That expresses in further increase in trade by services: export of the business service from the country where investment was placed to the investors' home country, and import of the business service to the FDI home country FDI.

Figure 3 presents a growing value of import of services by OECD countries. Increase in import gives the evidence to of growing importance of offshoring services, alike Other business activities.

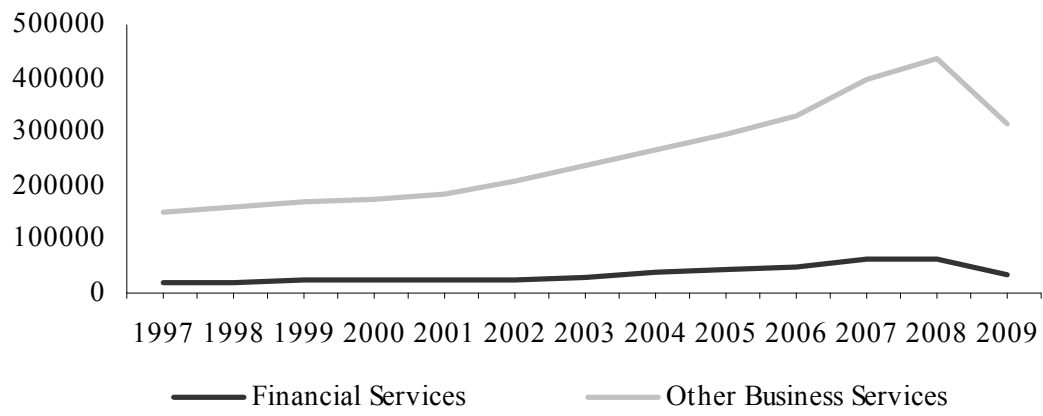

Note: aggregated data for: Austria, Belgium, Denmark, Finland, France, Germany, Italy, Japan, Netherlands, Spain, Sweden, United Kingdom, United States.

Fig. 3. Import of Other business services and Financial services by selected OECD countries (million US dollars)

Source: OECD Stat, http://stats.oecd.org/Index.aspx; data downloaded on 18.06.2011.

There is a clear trend of growth as FDI as well as import services in OECD countries. That is very likely that the role of services in international cooperation will be getting more and more important. So far, the index of outsourcing (the newest in OECD - 2000) of services is extremely low. According to OECD, average index was 0.08 for services in 2000 and 0.07 in 1995, whereas index for goods: 0.35 in 2000 and 0.31 in 1995. The lowest index of outsourcing abroad of goods in China, United States, and Japan is around 0.1-0.15, and still it is higher than average index of services. This index was counted on the basis of the Output-Input Tables 1995 and 2000, and OECD very rarely publishes the formal data.

Obviously, updated tables will provide new results that prove growing importance of services in international cooperation. 


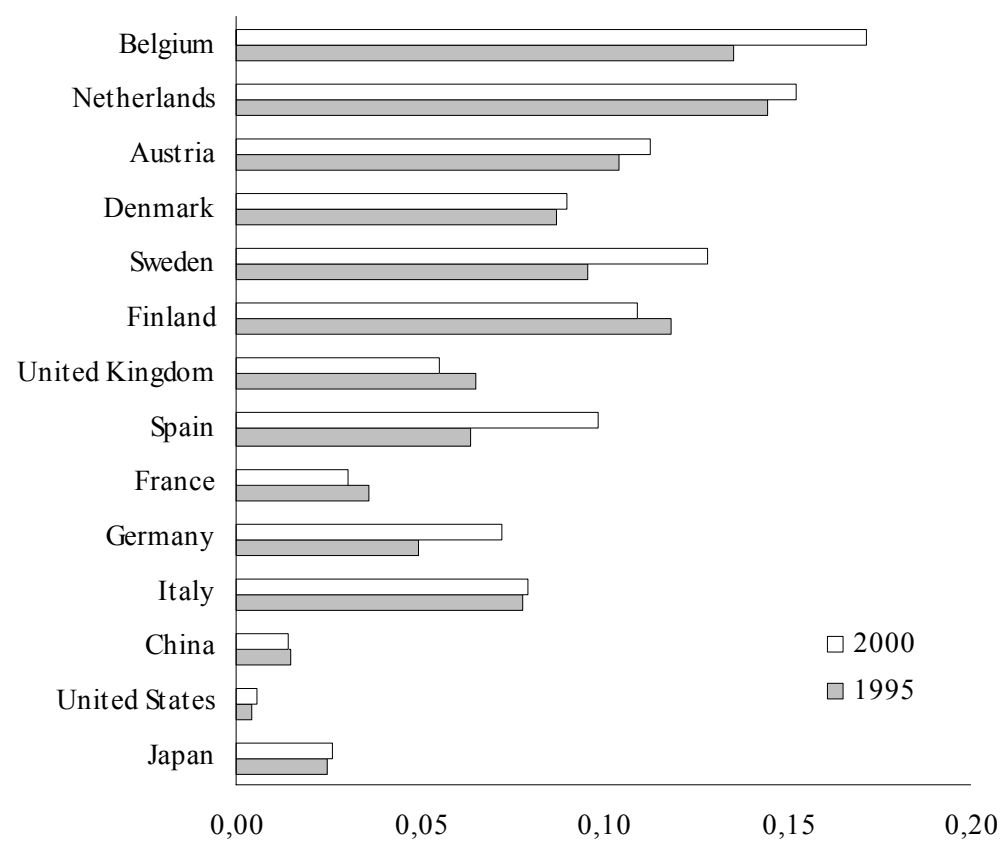

Fig. 4. Index of outsourcing abroad of services

Source: OECD, Input-Output database. StatLink: http://dx.doi.org/10.1787/731357412480; data downloaded on 18.03.2010.

Taking into account the effects ofFDI in business services (done by financial intermediations and Other business activities) on international cooperation - trade in services, we would expect some correlation between.

For aggregated data of 30 OECD countries the strongest relation (basis on the Pearson correlation) is found in FDI outward in Other business activities and import of Other business services. It seems that outward FDI in Other business activities highly affects import in this sector ${ }^{7}$. However, the results are slightly different in Poland, which is expected to be important FDI receivers in those sectors.

Pearson correlation coefficient in Poland is considered in two different periods. The first data does not cover the crisis effects. The first correlation values suggest, that the strongest relationship is between inflow of FDI in Other business activities and Export of Other business services. The correlation coefficient in this matter is much higher than in other cases.

Further analyze results confirm the expectation, that the crisis affected notably the international cooperation in business service sector. 
Table 2. Pearson correlation coefficient in developed countries (1995-2009)

\begin{tabular}{|c|c|c|}
\hline Pearson correlation coefficient & $\begin{array}{c}\text { FDI outward in Financial } \\
\text { Intermediation }\end{array}$ & FDI outward in OBA \\
\hline Import of Financial Services & 0.6558 & 0.9004 \\
\hline Import of OBS & 0.5783 & 0.9145 \\
\hline
\end{tabular}

1 - strong correlation

0 - no correlation

Source: own calculation.

On the base of many published comments we constantly faced with the growing value of offshoring investment in Poland. It is expected that increasing values of foreign investment is concentrated on the large group of business services defined in the category NACE code 74. Enumerated services will obviously result in growing number of offshoring projects located in the economy and consequently in increasing in export of Other business services (the statistical category, which make it possible to assess the values of offshoring in the country). Nevertheless, as the Pearson correlation coefficient shows, two additional years in analyze affected the results substantially.

Table 3. Pearson correlation coefficient in Poland (1995-2007)

\begin{tabular}{|c|c|c|}
\hline Pearson correlation coefficient & $\begin{array}{c}\text { FDI inward in Financial } \\
\text { Intermediation }\end{array}$ & FDI inward in OBA \\
\hline Export of Financial Services & 0.6706 & 0.7685 \\
\hline Export of OBS & 0.6634 & 0.9084 \\
\hline
\end{tabular}

Source: own calculation.

Table 4. Pearson correlation coefficient in Poland (1995-2009)

\begin{tabular}{|c|c|c|}
\hline Pearson correlation coefficient & $\begin{array}{c}\text { FDI inward in Financial } \\
\text { Intermediation }\end{array}$ & FDI inward in OBA \\
\hline Export of Financial Services & 0.713276 & 0.652345 \\
\hline Export of OBS & 0.725448 & 0.747566 \\
\hline
\end{tabular}

Source: own calculation.

Only two years of economic recession (2008-2009) resulted in the relationship of the analysis of the FDI and trade (see Table 4). There is no more strong correlation between FDI 
in Other business activities and export of Other business services, as it used to be revealed in analyzes of the period 1995-2007 (see Table 3).

However, strong correlation in FDI inward in Other business activities and export of Other business services draw my attention to the value of this indicators. Figure 5 represents values of export of Other business services with the respect to FDI inflow of Other business activities.

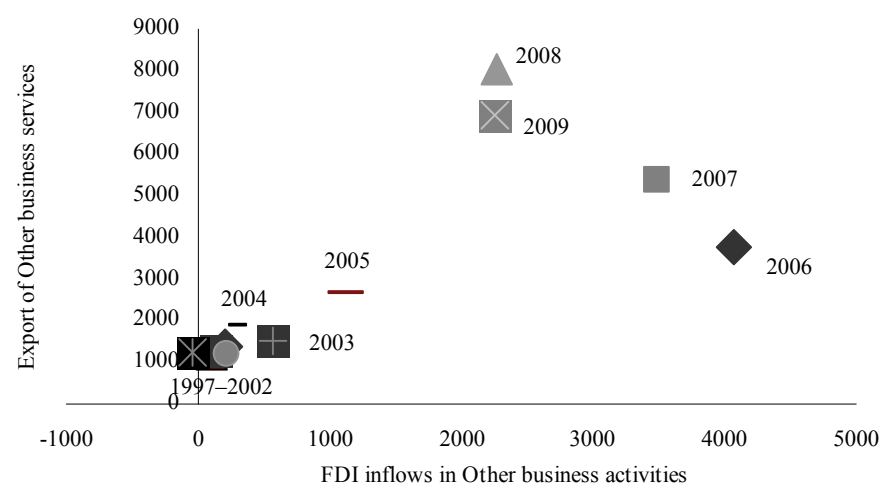

Fig. 5. FDI inflow in Other business activities with the relation to export of Other business services in Poland (million US dollars)

Source: own calculation based on OECD Stat, http://stats.oecd.org/Index.aspx; data downloaded on 18.06.2011.

There has been revealed a relationship between these two values. The picture above presents how both values were increasing. Concluding, we can state, that the growth in FDI inflow in Other business activities, was directly followed by the increasing values of export of Other business services to 2006 .

Many investors from the sector Other business activities started their businesses a few years ago, and serve other foreign companies in business activities ${ }^{8}$. So that, business activity pull export value up. It is proven in the regression functions for Poland. It is also not surprising after the detailed observation of offshoring projects imposed in Poland.

$$
\begin{aligned}
& E_{O B S}=\underset{(330.19)}{509} \underset{(0.17)}{0.4538} F D I_{i n F I}+\underset{(0.1107)}{0.7234} F D I_{\text {inOBA }} \\
& R^{2}=0.81
\end{aligned}
$$

where $^{9}$ :

$E_{O B S}-$ export of Other business services,

$F D I_{\text {inFI }}-$ FDI inflow in Financial Intermediation,

$F D I_{\text {in } O B A}-$ FDI inflow in Other business activities. 
Presented regression functions demonstrate different relationship between FDI inflow in Other business activities and Financial intermediation to export of Other business services. After the analyze of previous evidence, we expect a strong dependence FDI and export of services in Poland.

The regression function counted for Poland revealed strong impact of FDI inflow in Other business activities on export of Other business services. Rising activity of foreign investment in Other business activities entails export growth in Other business services.

As further analyze proved, Hungary or Czech Republic do not characterize this phenomenon as Poland does.

As the report of ABSL states, almost all business service centers located in Poland (91\%) provide services for foreign clients, mostly from Western Europe. Our country is now more attractive that Egypt or Tunisia, where unstable political and economic environment put off foreign investors. At the beginning of 2011 Egypt, for instance, has been recognized in AT Kearney Report (Global Service Location Index) as one of the most attractive location for business service centers - on 4 rank (Poland - 24 rank). Political stability in Poland as well as in all CEE region strengthen our position on the map of attractive location of business. Another factors determining the attractiveness of our country are cultural closeness to Western Europe, and better adjusting of graduates' skills to the needs of business service sector. Poland offer investment attractiveness not based on costs or labor force volume, but much more important in sophisticated business service - skills, knowledge, and human capital.

\section{Conclusions}

This paper investigates effects of foreign direct investment in business services mostly done as offshoring investment. The empirical results allow making three important statements. First of all, we face with overall trend of growth of services, and the expansion will be continued because companies tend to outsource a growing share of their business support functions (accounting, computer maintenance, contact with customers, generally "Other business services") to external provides of services and these services become more and more important in international trade ${ }^{10}$.

According to UNCTAD survey ${ }^{11}$ food and beverages and business services are among the industries whose FDI plans over the next three years are the most optimistic. Business services sector is less affected by crisis, because it is not so sensitive than manufacturing is. There 
are a plenty of optimistic prospects for growth of this sector in mid-term, especially in CEE countries, where FDI inflow in Other business activities is concentrated.

Secondly, Polish export of business services, specific for offshoring, is mainly driven by FDI inflow in Other business activities. So that, ongoing crisis probably accelerates this trend due to many companies recognize offshoring as an opportunity to reduce internal costs by externalizing non-core business activities. In Poland there are 282 service centers (205 BPO/ SSC, 77 R\&D) run by 220 foreign investors from 22 countries. The employment in the business service sector has increased by $50 \%$ for the last two years. In Wroclaw, particularly, it has risen by $100 \%$.

Finally, continuing trend towards a rising preferences for emerging economies in MNCs gives strong impetus to the trend of internationalization of services reducing the gap between internationalization of goods and services and intensify the specialization of emerging economies in business services sector.

The paper tackles a question if crisis will accelerate cooperation and restructure/redesign business services, especially done by financial institutions suffered the most after autumn 2008. This question has been answered only partially, because of a lack of statistics in FDI as well as export in 2010. However, I would raise a general conclusion, that crisis in 2001-2002 affected allocation of the production processes in manufacturing to China and India and crisis in 2008 will result in internationalization of services, relocation of services, progressive recovery of FDI - growing internationalization, a wave of international investment projects located in developing countries and new UE12, especially business services to CEE countries.

\section{Notes}

1 Schumpeter (1982, 1939).

2 Business Services Sector in Poland, (2011).

3 UNCTAD (2011).

4 Data from Association of Business Service Leaders in Poland.

5 Eller, Haiss, Steiner (2006).

6 According to OECS, Other business services covers trade-related services, operational leasing services (rental), legal, accounting, management consulting, and public relation services, advertising, market research and public opinion, polling services, research and development services, architectural, engineering and other technical services.

7 Other business activities (data on FDI), Other business services (data on Trade): NACE code 74: legal activities, accounting, book-keeping and auditing activities; tax consultancy, market research and public opinion polling, business and management consultancy activities, management activities of holding companies, architectural and engineering activities and related technical consultancy, technical testing and analysis, advertising, labor recruitment and provision of personnel, investigation and security activities, industrial cleaning, miscellaneous business activities n.e.c., photographic activities, packaging activities, secretarial and translation activities. 
8 Bevan, Estrin (2004).

9 Data for analysis from OECD Stat, http://stats.oecd.org/Index.aspx.

${ }^{10}$ Ouyang (2005).

${ }^{11}$ UNCTAD (2009).

\section{References}

Alfaro, L., Chanda, A., Kalemli-Ozcan, S., Sayek, S. (2004). FDI and economic growth: the role of local financial markets, Journal of International Economics, pp. 89-112.

Bevan, A., Estrin, S. (2004). The determinants of foreign direct investment into European transition economies, Journal of Comparative Economics, pp. 775-787.

Business Services Sector in Poland. (2011). Association of Business Service Leaders in Poland, Warsaw.

Eller, M., Haiss, P., Steiner, K. (2006). Foreign direct investment in the financial sector and economic growth in Central and Eastern Europe: The crucial role of the efficiency channel, Emerging Markets Review, pp. 300-319.

Carreira, C., Teixeira, P. (2007). Internal and External Restructuring over the Cycle: A FirmBased Analysis of Gross Flows and Productivity Growth in Portugal, Grupo de Estudos Monetários e Financeiros, No. 1.

Ouyang, M. (2005). The Scarring Effect of Recessions, Working paper No. 050609, Irvine: University of California-Irvine, Department of Economics, p. 40.

Schumpeter, J.A., (1982, 1939), Business cycles: a theoretical, historical, and statistical analysis of the capitalist process, Philadelphia: Porcupine Press.

UNCTAD, (2009). World Investment Prospects Survey 2009-2011.

UNCTAD, (2011). World Investment Report 2011.

UNCTAD/International Trade Center, (2008), Investment map: Locations Competing for Investment Attraction in Selected Industries. 